\title{
Excellent Combination of HPLC-RSD-DAD-ESI/MS and HSCCC Experiments to Screen and Identify Radical Scavengers from Neo-Taraxacum siphonanthun
}

\author{
Xinyu Jiang,* Shuyun Shi, Yuping Zhang and Xiaoqing Chen \\ School of Chemistry and Chemical Engineering, Central South University, \\ Changsha 410083, P.R. China
}

\begin{abstract}
Em nossas pesquisas anteriores encontramos que o extrato bruto de Neo-T. siphonanthun apresentou atividade eficaz para captura de radicais DPPH (1,1-difenil-2-picrilidazida). Neste estudo, um método de triagem rápida online, através de um sistema de cromatografia líquida de alta eficiência com detector por captura de radicais, acoplada a detector por arranjo de diodos e espectrometria de massas com ionização por eletrospray (HPLC-RSD- DAD-ESI/MS) foi desenvolvido para a procura de antioxidantes individuais a partir da fração mais ativa. Três derivados isoméricos foram detectados. Os compostos-alvo ativos foram isolados por cromatografia em contracorrente de alta velocidade (CCC-AV) com pureza superior a 99\%, e foram identificados como luteolina-3'-O- $\beta$-D-glicopiranosídeo (1), luteolina-7-O- $\beta$-D-glicopiranosídeo (2) e luteolina4'-O- $\beta$-D-glicopiranosídeo (3) por análise de seus espectros de ressonância magnética nuclear (RMN). A atividade antioxidante dos três compostos foi avaliada pelo ensaio DPPH off-line, e todos eles mostraram atividade potente.
\end{abstract}

Our previous research found that the crude extract of Neo-T. siphonanthun exhibited an effective DPPH (1,1-diphenyl-2-picryhydrazyl) radical scavenging activity. In this study an online rapid screening method, high-performance liquid chromatography-radical scavenging detection-diode array detector-electrospray ionization mass spectrometry (HPLC-RSD- DAD-ESI/MS) system, was developed for screening individual antioxidants from the most active fraction. Accordingly, three isomeric derivatives were detected. The target active compounds were isolated by highspeed counter-current chromatography (HSCCC) with the purity over $99 \%$, and were identified as luteolin-3'-O- $\beta$-D-glucopyranoside (1), luteolin-7- $O$ - $\beta$-D-glucopyranoside (2) and luteolin-4'$O$ - $\beta$-D-glucopyranoside (3) by analysis of its off-line nuclear magnetic resonance (NMR) spectra. Antioxidant activity of three compounds was assessed by off-line DPPH assay, and all of them showed potent activity.

Keywords: HPLC-RSD-DAD-ESI/MS, radical scavenger, flavonoid, HSCCC, Neo-Taraxacum siphonanthun

\section{Introduction}

Neo-Taraxacum siphonanthun (Asteraceae) is a species found in Inner Mongolia, China. It is the only one subjected to a new genus, Neo-Taraxacum, because of the different shape of the ligulate flowers with those in Taraxacum genus. ${ }^{1,2}$ This species has commonly been used by Chinese local people for both medicinal and dietary purposes. However, to our best knowledge, there have been no published reports on the chemical constituents and pharmacological properties of this species. Our previous research showed its crude extract exhibited a high DPPH radical scavenging activity, and therefore it might be a

*e-mail: jiangxinyu@mail.csu.edu.cn good candidate for further development as antioxidant remedies. Moreover, antioxidants have received a great amount of attention as being primary preventive ingredients against various diseases. ${ }^{3}$ Therefore, further chemical and pharmacological research of Neo-T. siphonanthun is warranted.

Activity-guided fractionation of plant extracts is a time-consuming, labor intensive and expensive process, and often leads to loss of activity during the isolation and purification procedures due to dilution effects or decomposition. ${ }^{4}$ Therefore, an online HPLC-RSD (DPPH) method was developed for screening complex mixtures for radical scavenging components from complex extracts. ${ }^{5-10}$ Such techniques allowed for a rapid and selective detection of radical scavenging substances 
in the presence of many inactive constituents with a minimum of sample preparation. Furthermore, the HPLCRSD method coupled online to MS would permit the rapid determination of antioxidant activity and provide structural identification of the antioxidant compounds. ${ }^{11}$ However, on most occasions, even for isomeric natural products the MS data were insufficient for the exact structure elucidation of plant secondary products because of the lack of reference standards and MS database, and at this time NMR frequently remained necessary.

The aim of the present paper, therefore, was to screen and isolate the radical scavenging compounds from the most active fraction of Neo-T. siphonanthun by online HPLC-RSD-DAD-ESI/MS method. Three antioxidants, luteolin-3'-O- $\beta$-D-glucopyranoside (1), luteolin-7$O$ - $\beta$-D-glucopyranoside (2) and luteolin-4' $-O$ - $\beta$-Dglucopyranoside (3) (Figure 1), were isolated using HSCCC and exactly elucidated by NMR experiments.

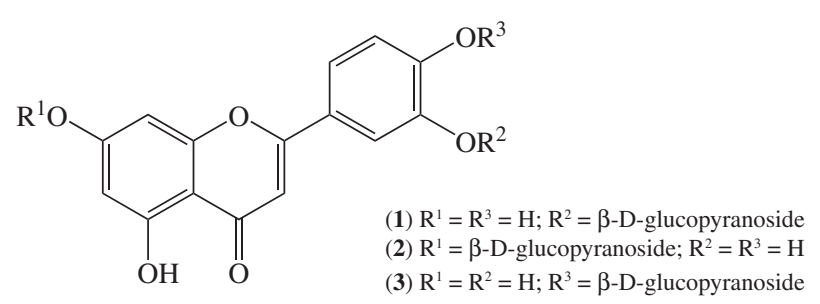

Figure 1. The chemical structure of luteolin-3'-O- $\beta$-D-glucopyranoside (1), luteolin-7-O- $\beta$-D-glucopyranoside (2) and luteolin-4'-O- $\beta$-Dglucopyranoside (3).

\section{Experimental}

\section{Chemicals and reagents}

Ethanol, $n$-hexane, $n$-butanol and methanol for preparation of active fraction and HSCCC separation were analytical grade and purchased from Chemical Reagent Factory of Hunan Normal University (Hunan, China). Methanol used for analytical HPLC was of chromatographic grade (Merk, Darmatadt, Germany). All aqueous solutions were prepared with pure water produced by Milli-Q water (18.2 M ) system (Millipore, Bedford, MA, USA). D101 macroporous resin was purchased from the Chemical Plant of Nankai University (Tianjin, China), which was cross-linked styrene and divinylbenzene copolymer. 1,1-diphenyl-2-picrylhydrazyl radical (DPPH·, 95\%) was bought from Sigma-Aldrich (Steinheim, Germany), and DPPH radical solutions were freshly prepared in methanol every day and kept protected from light. Multi-well plates (Greiner) and multi-well plates readers (Bio-Tek Instruments, USA) were used in the antioxidant activity experiments. Neo-Taraxacum siphonanthun was purchased from Bozhou, Anhui Province in November, 2006, and identified by Prof. Juanhua Xu, College of Pharmaceutical Sciences, Zhejiang University.

\section{Preparation of extracts}

The pulverized material of Neo-T. siphonanthun $(2.0 \mathrm{~kg}$ ) was extracted with $10 \mathrm{~L} 95 \%$ ethanol under reflux for $3 \mathrm{~h}$ and concentrated under reduced pressure to give a brown syrup (217 g). A portion of this syrup (200 g) was then subjected to column chromatography $(25.0 \mathrm{~cm} \times 200 \mathrm{~cm}$, contained $3.0 \mathrm{~kg}$ D101 macroporous resin) and eluted with $\mathrm{MeOH}-\mathrm{H}_{2} \mathrm{O}$ step gradients to yield five main fractions: $\mathrm{F}_{1}$ (10\% methanol aqueous solution), $\mathrm{F}_{2}$ (30\% methanol aqueous solution), $\mathrm{F}_{3}$ (50\% methanol aqueous solution), $\mathrm{F}_{4}(70 \%$ methanol aqueous solution) and $\mathrm{F}_{5}(90 \%$ methanol aqueous solution).

\section{HPLC analyses}

Analytical HPLC was consisted of two LC-8A pumps, a Prominence SPD-M20A diode array detector performing the wavelength scanning from 190 to $950 \mathrm{~nm}$, a manual injection valve with a $20 \mu \mathrm{L}$ loop and an LC Solution workstation (Shimadzu, Japan). The target compounds were separated by using a reversed phase Symmetry ${ }^{\circledR} \mathrm{C}_{18}$ ( $250 \mathrm{~mm} \times 4.6 \mathrm{~mm}$ i.d., $5 \mu \mathrm{m}$, Milford, MA, USA) column and a security guard $\mathrm{C}_{18}$ ODS $(4.0 \mathrm{~mm} \times 3.0 \mathrm{~mm}$ i.d. $)$ from Phenomenex (Torrance, California, USA). The mobile phase was consisted of A ( $0.1 \%$ aqueous acetic acid) and $\mathrm{B}$ (methanol), which was programmed as follows: from 0 to $8 \mathrm{~min}, 20 \% \mathrm{~B}(80 \% \mathrm{~A}), 8-25 \mathrm{~min}$, linear increase from $20 \%$ to $40 \%$ B ( $80 \%$ to $60 \%$ A). The flow rate was $0.8 \mathrm{~mL} \mathrm{~min}^{-1}$ while the ambient temperature was controlled at $20{ }^{\circ} \mathrm{C}$ by air conditioner. Spectra were recorded from 200 to $500 \mathrm{~nm}$ (peak width $0.2 \mathrm{~min}$ and data rate $1.25 \mathrm{~s}^{-1}$ ) while the chromatogram was acquired at $254 \mathrm{~nm}$.

\section{Online HPLC-RSD-DAD-ESI/MS analysis}

An online HPLC-RSD-ESI/MS method was described for a rapid detection of radical scavenging components by using a methanol solution of DPPH stable free radicals. ${ }^{10,11}$ Analytical HPLC was performed on Acquity ${ }^{\mathrm{TM}}$ UPLC system (Waters Corp., Milford, MA, USA) with cooling autosampler and column oven enabling temperature control of the analytical column. Separation was performed on a Symmetry ${ }^{\circledR} \mathrm{C}_{18}$ column $(150 \mathrm{~mm} \times 3.9 \mathrm{~mm}$ i.d., $5 \mu \mathrm{m})$ at $25{ }^{\circ} \mathrm{C}$. The stationary phase and the elution gradient were the same as those in the HPLC analysis. The active fraction was dissolved in methanol and injected into the 
HPLC system. Before delivering into the system the solvent was filtered through $0.45 \mu \mathrm{m}$ PTEE filter and degassed using vacuum. The auto-sampler was conditioned at $10^{\circ} \mathrm{C}$ and the injection volume was $10 \mu \mathrm{L}$. The flow rate was $0.8 \mathrm{~mL} \mathrm{~min}{ }^{-1}$ at $20{ }^{\circ} \mathrm{C}$. The compounds eluted from the column were split into two streams using an adjustable high-pressure stream splitter. One part $\left(0.6 \mathrm{~mL} \mathrm{~min}^{-1}\right)$ was continuously monitored by PAD detector and MS. Triplequadrupole tandem mass spectrometric detection was carried out on a Micromass ${ }^{\circledR}$ Quattro micro ${ }^{\text {TM }}$ API mass spectrometer (Waters Corp., Milford, MA, USA) with an electrospray ionization (ESI) interface. The ESI source was set in positive ionization mode. The following settings were applied to the instrument: capillary voltage, $3.00 \mathrm{kV}$; cone voltage, $40.0 \mathrm{~V}$; extractor voltage, $3.00 \mathrm{~V}$; source temperature, $120{ }^{\circ} \mathrm{C}$; desolvation temperature, $400{ }^{\circ} \mathrm{C}$; desolvation gas flow, $750 \mathrm{~L} \mathrm{~h}^{-1}$; cone gas flow, $50 \mathrm{~L} \mathrm{~h}^{-1}$, dwell time, $0.05 \mathrm{~s}$. Nitrogen was used as the desolvation and cone gas. Mass detection was performed in full scan mode for $m / z$ in the range 160-600. All data collected were acquired and processes using MassLynx ${ }^{\mathrm{TM}} \mathrm{NT} 4.1$ software with QuanLynx ${ }^{\mathrm{TM}}$ program (Waters Corp., Milford, MA, USA). The other part $\left(0.2 \mathrm{~mL} \mathrm{~min}^{-1}\right)$ was used for the radical scavenging detection. The length of the capillary used for the post-column reaction was adjusted to achieve a reaction time of $0.6 \mathrm{~min}$. The antioxidants reacted post-column with the DPPH radical at a concentration of $50 \mathrm{mg} \mathrm{L}^{-1}$ in methanol. The flow of the DPPH radical solution was set to $0.4 \mathrm{~mL} \mathrm{~min}^{-1}$. The DPPH radical scavenging detection chromatogram is detected as a negative peak at $517 \mathrm{~nm}$ with a variable wavelength PC300 detector and the chromatograms were accordingly recorded on a model SCJS-3000 workstation (Tianjin Scientific Instrument Ltd., Tianjin, China).

\section{HSCCC separation}

The preparative HSCCC was performed on a sealfree high-speed counter-current chromatography by Prof. Qizhen Du (Institute of Food and Biological Engineering, Zhejiang Gongshang University, Hangzhou, China). The apparatus was equipped with a polytetrafluoroethylene (PTFE) multi-layer coiled column with an average I.D. of $2.6 \mathrm{~mm}$ and a total volume of $420 \mathrm{~mL}$. The column revolves around its own axis at the angular velocity in the same direction. The revolution speed of the apparatus could be regulated between 0 and $1000 \mathrm{rpm}$. The revolution radius or the distance between the holder axis and central axis of the centrifuge was $8 \mathrm{~cm}$, and the $\beta$ value of the coils from the inner layer to the outer layer is $0.50-0.79 . \beta=r / R$, where $r$ is the distance from the coil to the holder shaft and $\mathrm{R}$ is the revolution radius or the distance between the holder axis and central axis of the centrifuge. The solvent was pumped into the tubing with a FMI pump (Zhejiang Instrument Factory, Hangzhou, China). The effluent was continuously monitored with a variable wavelength PC300 detector at $254 \mathrm{~nm}$ and the chromatogram with a model SCJS-3000 workstation (Tianjin Scientific Instrument Ltd., Tianjin, China). A manual sample injection valve with a $20 \mathrm{~mL}$ loop was connected to the system. The suitable solvent systems were evaluated by HPLC according to the partition coefficients (K). The solvent system composed of $n$-hexane$n$-butanol-water (1:1:2) was used for the separation of active fraction $\mathrm{F}_{3}$ with the upper phase as the stationary phase. The sample solution was prepared by dissolving $500 \mathrm{mg}$ of the enriched active fraction in $20 \mathrm{~mL}$ of the lower phase of the solvent system for isolation and purification. HSCCC was performed as follows: the multiplayer coiled column was first entirely filled with the upper phase. The lower mobile phase was then pumped into the inlet of the column at the flow rate of $1.5 \mathrm{~mL} \mathrm{~min}^{-1}$, while the apparatus was run at $800 \mathrm{rpm}$. After hydrodynamic equilibrium was reached, indicated by a clear mobile phase eluting at the tail outlet, a sample $(500 \mathrm{mg}$ ) dissolved in $20 \mathrm{~mL}$ of the upper phase was injected into the injection valve. The effluent from the outlet of the column was continuously monitored with a UV detector at $254 \mathrm{~nm}$ and the peak fractions were collected manually according to the chromatographic profile. After target compounds were eluted, the centrifuge was stopped and the column contents were fractionated by continuously eluting the column with the mobile phase. The effluent was collected for purity analysis.

\section{Identification of radical scavengers}

Identification of the target compounds was accomplished by their spectroscopic spectra, mass data and NMR spectra. The NMR experiments were performed on a VARIAN INOVA-400 (Varian Corporation, USA) NMR spectrometer. The reference compound TMS was used as internal standard for the determination of chemical shifts.

\section{Off-line DPPH radical assay}

The DPPH radical assay was performed as described. ${ }^{12}$ The free radical scavenging efficiency of the compounds was determined by decoloration of the DPPH radical. In brief, $25 \mu \mathrm{L}$ of diluted sample $\left(4 \mathrm{mg} \mathrm{mL}^{-1}\right.$ dissolved in DMSO) mixed with $40 \mu \mathrm{L}$ DPPH·methanol solution $\left(0.4 \mathrm{mg} \mathrm{mL}^{-1}\right)$ and made up with methanol to a final volume of $250 \mu \mathrm{L}$. The methanol solution of DPPH. was served as a control. The absorbance was measured at $517 \mathrm{~nm}$ 
after the mixture was incubated at $37^{\circ} \mathrm{C}$ for $30 \mathrm{~min}$. The antiradical activity is expressed as percentage of DPPH radical elimination calculated according to the following formula: $\left[\left(\mathrm{A}_{\text {blank }}-\mathrm{A}_{\text {sample }}\right) / \mathrm{A}_{\text {sample }}\right] \times 100$, where $\mathrm{A}_{\text {blank }}$ is the absorbance of the DPPH radical solution and $\mathrm{A}_{\text {sample }}$ is the absorbance of the DPPH radical solution after the addition of the sample. Sample concentration providing 50\% inhibition $\left(\mathrm{IC}_{50}\right)$ was calculated from the graph plotting inhibition percentage. All tests were run in triplicate, and the average value was calculated.

\section{Results and Discussion}

\section{Antioxidant activity of different fractions of Neo-T. siphonanthun}

The ethanol extract of Neo-T. siphonanthun was separated by D101 column chromatography to yield five fractions, and the radical scavenging activity of each fraction was evaluated using an off-line DPPH assay. The $\mathrm{F}_{3}$ fraction (50\% ethanol aqueous solution) showed potent capacity to scavenge DPPH radical compared with other fractions (Table 1), then HPLC-RSD-DAD-ESI/MS and HSCCC methods were applied to screen and isolate the active compounds from this active fraction.

Table 1. DPPH radical scavenging capacity of fractions recovered from the ethanol extract of Neo-T. Siphonanthun

\begin{tabular}{lcc}
\hline Fractions & $\begin{array}{c}\text { Concentration/ } \\
\left(\mathrm{mg} \mathrm{mL}^{-1}\right)\end{array}$ & $\begin{array}{c}\text { DPPH radical } \\
\text { inhibition } \pm \mathrm{SD} /(\%)^{\mathrm{a}}\end{array}$ \\
\hline $\mathrm{F}_{1}$ & 4 & $5.7 \pm 0.8$ \\
$\mathrm{~F}_{2}$ & 4 & $18.2 \pm 1.1$ \\
$\mathrm{~F}_{3}$ & 4 & $43.1 \pm 3.5$ \\
$\mathrm{~F}_{4}$ & 4 & $27.6 \pm 1.2$ \\
$\mathrm{~F}_{5}$ & 4 & $20.4 \pm 2.4$ \\
\hline
\end{tabular}

${ }^{\mathrm{a}}$ Each value is the mean of triplicate measurements and the standard deviation (SD).

\section{Online HPLC-RSD-DAD-ESI/MS analysis}

The online HPLC-RSD-DAD-ESI/MS method was used for a rapid detection and identification of radical scavenging components in complex mixtures with a minimum of sample preparation. The more rapidly the absorbance decreases, the more potent the antioxidant activity of the compound is in terms of hydrogendonating ability. UV (positive) and DPPH (negative) radical scavenging detection chromatograms are shown in Figure 2, which suggested that the active fraction contained at least six compounds, and three compounds
(1-3) showed inhibitory activity to scavenge DPPH radical. Moreover, compounds 1-3 had the similar characteristic UV spectra which probably suggested they were the luteolin derivatives. Meanwhile, compounds 1-3 presented the same pseudomolecular ion at $m / z 449[\mathrm{M}+\mathrm{H}]^{+}$and a fragment was observed at $\mathrm{m} / \mathrm{z} 287[(\mathrm{M}+\mathrm{H})-162]^{+}$. This indicated a hexose as the sugar of the $O$-glycosylation and luteolin as the aglycone, which suggested that three antioxidant compounds were the isomeric compounds of luteolin- $O$-hexoside, and the probable difference among them was the type and position of the aglycone (Figure 3). But for the exact structural identification of these three isomeric compounds, NMR was necessary. Because of the similar molecules, separation and purification of them by conventional methods usually require multiple chromatography steps. Therefore, HSCCC was used to isolate them.

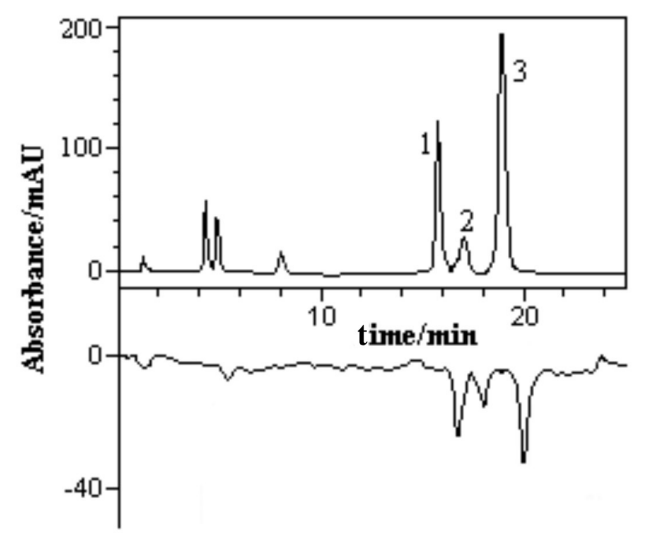

Figure 2. Combined HPLC-UV and DPPH radical scavenging detection chromatograms of active extract from $\mathrm{F}_{3}$ fraction of Neo-T. siphonanthun extract. Peaks 1,2 and 3 correspond to luteolin-3'-O- $\beta$-Dglucopyranoside, luteolin-7-O- $\beta$-D-glucopyranoside and luteolin-4'- $O$ $\beta$-D-glucopyranoside.

\section{Substances isolated by HSCCC}

HSCCC, first assembled by Ito, ${ }^{13}$ is a support-free liquidliquid chromatographic technique with no solid support matrix, and separation is based on fast partitioning effects of the analytes between two immiscible liquid phases. This method has been successfully applied to separate and isolate active components from natural products. ${ }^{14,15}$

$500 \mathrm{mg}$ of the active extract from $\mathrm{F}_{3}$ fraction of Neo-T. siphonanthun extract was performed by HSCCC with a biphasic solvent system composed of $n$-hexane- $n$-butanolwater $(1: 1: 2, \mathrm{v} / \mathrm{v})$ using the upper phase as the stationary phase. Three fractions (1-3) were obtained in one-step elution less then $6 \mathrm{~h}$ as shown in Figure $4 \mathrm{a}$, which is $26.3 \mathrm{mg}$ of fraction 1 (collected during 145-180 min), $7.8 \mathrm{mg}$ of fraction 2 (collected during 200-225 $\mathrm{min}$ ) and $49.5 \mathrm{mg}$ 

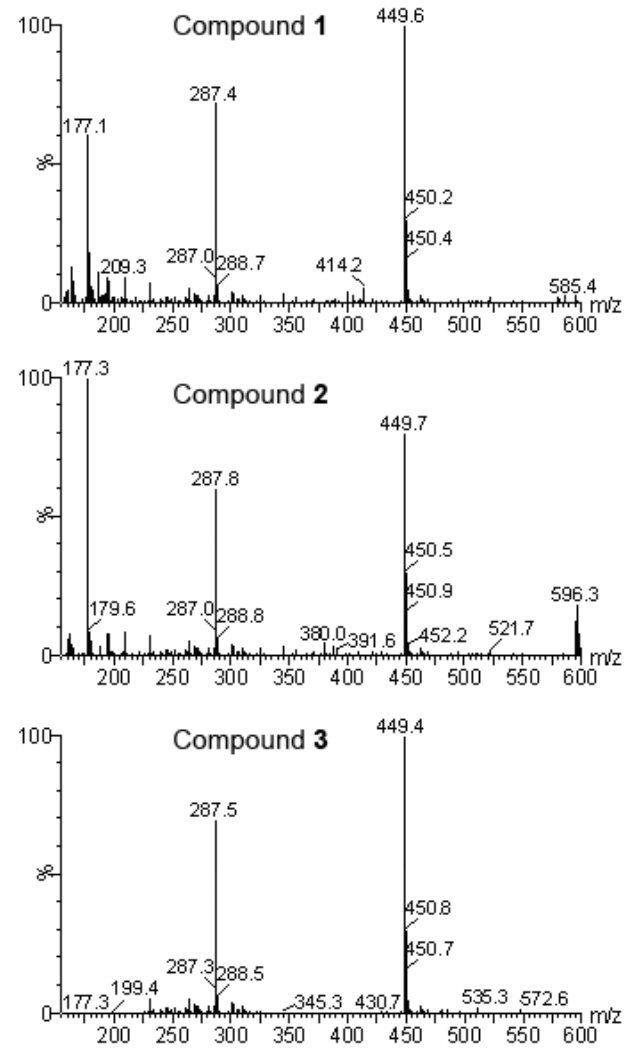

Figure 3. Mass spectral data of compound 1-3 measured in the ESI positive mode.

of fraction 3 (collected during 238-280 min). HPLC analysis of each HSCCC fraction revealed that three pure antioxidants could be obtained from the enriched extract. The purity of these compounds was $99.5,99.2$ and $99.4 \%$, respectively (Figure $4 b$ ).

\section{Identification of antioxidant compounds}

Identification of each $\mathrm{HSCCC}$ fraction was carried out by UV, ${ }^{1} \mathrm{H}$ NMR, ${ }^{13} \mathrm{C}$ NMR and $2 \mathrm{D}$ NMR, which were in agreement with published data. ${ }^{16}$

\section{Compound 1 (luteolin-3'-O- $\beta$-D-glucopyranoside)}

Yellow amorphous powder; $\mathrm{UV}(\mathrm{MeOH}) \lambda_{\max } / \mathrm{nm}: 268$, 339; ${ }^{1} \mathrm{H}$ NMR $\left(\mathrm{C}_{5} \mathrm{D}_{5} \mathrm{~N}, 400 \mathrm{MHz}\right) \delta 7.90(1 \mathrm{H}, \mathrm{dd}, J 8.4,2.0$ Hz, H-6'), 7.51 (1H, d, J 2.0 Hz, H-2'), 7.49 (1H, d, J 8.0 Hz, H-5'), 7.01 (1H, d, J 2.0 Hz, H-8), 6.83 (1H, s, H-3), $6.82(1 \mathrm{H}, \mathrm{d}, J 2.0 \mathrm{~Hz}, \mathrm{H}-6), 5.80(1 \mathrm{H}, \mathrm{d}, J 7.2 \mathrm{~Hz}, \mathrm{H}-1$ ”), 3.35-4.65 (5H, H-2"'-H-6"); ${ }^{13} \mathrm{C}$ NMR $\left(\mathrm{C}_{5} \mathrm{D}_{5} \mathrm{~N}, 100 \mathrm{MHz}\right)$ $\delta 182.9$ (s, C-4), 165.5 (s, C-7), 164.1 (s, C-2), 162.7 (s, C-9), 158.0 (s, C-5), 152.0 (s, C-4'), 147.9 (s, C-3'), 122.8 (d, C-6'), 119.8 (s, C-1'), 116.9 (d, C-5'), 114.8 (d, C-2'), 106.8 (s, C-10), 104.2 (d, C-3), 101.9 (d, C-1"), 100.7 (d, C-6), 95.5 (d, C-8), 79.2 (d, C-5”), 78.6 (d, C-3"), 74.6 (d, C-2"), 71.3 (d, C-4"), 62.5 (t, C-6").

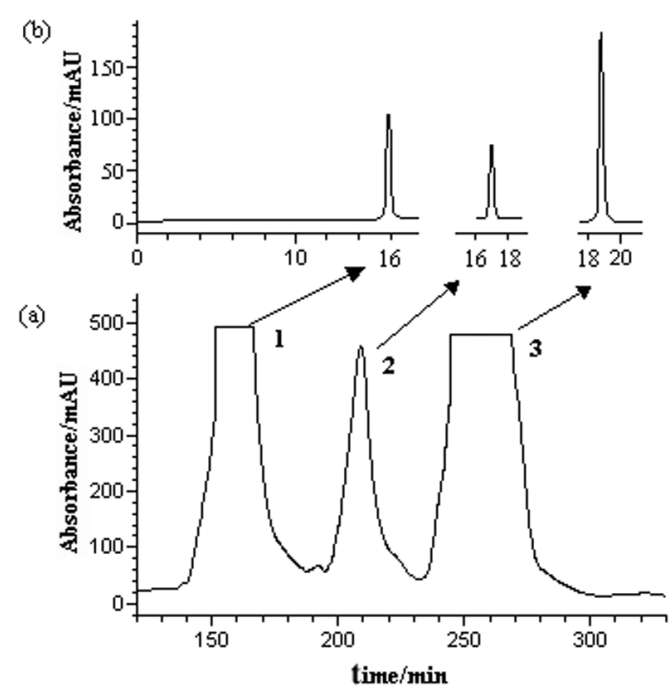

Figure 4. (a) Preparative HSCCC separation of the enriched sample from $\mathrm{F}_{3}$ fraction of Neo-T. Siphonanthun extract. (b) HPLC chromatogram of HSCCC fractions. The chromatographic conditions were the same with those in the Figure 2. Fractions 1, 2 and 3 correspond to luteolin-3'-O$\beta$-D-glucopyranoside, luteolin-7- $O$ - $\beta$-D-glucopyranoside and luteolin4'-O- $\beta$-D-glucopyranoside.

Compound 2 (luteolin-7-O- $\beta$-D-glucopyranoside)

Yellow amorphous powder; $\mathrm{UV}(\mathrm{MeOH}) \lambda_{\max } / \mathrm{nm}: 253$, 268,$345 ;{ }^{1} \mathrm{H}$ NMR (DMSO- $\left.d_{6}, 400 \mathrm{MHz}\right) \delta 12.96(1 \mathrm{H}, \mathrm{br}$ s, 5-OH), $7.44(1 \mathrm{H}, \mathrm{dd}, J$ 8.4, $2.0 \mathrm{~Hz}, \mathrm{H}-6$ ') $7.42(1 \mathrm{H}, \mathrm{d}, J$ $2.0 \mathrm{~Hz}, \mathrm{H}-2$ '), 6.91 (1H, d, $J 8.0 \mathrm{~Hz}, \mathrm{H}-5$ '), $6.77(1 \mathrm{H}, \mathrm{d}, J$ $2.0 \mathrm{~Hz}, \mathrm{H}-8), 6.72(1 \mathrm{H}, \mathrm{s}, \mathrm{H}-3), 6.45(1 \mathrm{H}, \mathrm{d}, J 2.0 \mathrm{~Hz}, \mathrm{H}-6)$, 5.07 (1H, d, J 7.2 Hz, H-1"), 3.20-3.95 (5H, H-2"-H-6"); ${ }^{13} \mathrm{C}$ NMR (DMSO- $\left.d_{6}, 100 \mathrm{MHz}\right) \delta 182.3$ (s, C-4), 164.9 (s, C-2), 163.4 (s, C-7), 161.6 (s, C-9), 157.4 (s, C-5), 150.4 (s, C-4'), 146.2 (s, C-3'), 121.8 (d, C-6'), 119.6 (s, C-1'), 116.4 (d, C-5'), 114.0 (d, C-2'), 105.8 (s, C-10), 103.6 (d, C-3), 100.3 (d, C-1"), 99.9 (d, C-6), 95.2 (d, C-8), 77.6 (d, C-5"), 76.8 (d, C-3"), 73.6 (d, C-2"), 69.9 (d, C-4"), 61.1 (t, C-6").

\section{Compound 3 (luteolin-4'-O- $\beta$-D-glucopyranoside)}

Yellow amorphous powder; UV (MeOH) $\lambda_{\max } / \mathrm{nm}: 268$, 336; ${ }^{1} \mathrm{H}$ NMR (DMSO- $d_{6}$, $\left.400 \mathrm{MHz}\right) \delta 12.95(1 \mathrm{H}$, br s, 5-OH), 7.55 (1H, d, J 2.0 Hz, H-2'), 7.51 (1H, dd, $J$ 8.4, $2.0 \mathrm{~Hz}, \mathrm{H}-6$ ') $7.23(1 \mathrm{H}, \mathrm{d}, J 8.0 \mathrm{~Hz}, \mathrm{H}-5$ '), $6.82(1 \mathrm{H}, \mathrm{s}, \mathrm{H}-3)$, $6.50(1 \mathrm{H}, \mathrm{d}, J 2.0 \mathrm{~Hz}, \mathrm{H}-8), 6.20(1 \mathrm{H}, \mathrm{d}, J 2.0 \mathrm{~Hz}, \mathrm{H}-6), 4.89$ (1H, d, J 7.2 Hz, H-1"), 3.11-3.79 (5H, H-2"-H-6"); ${ }^{13} \mathrm{C}$ NMR (DMSO- $d_{6}, 100$ MHz) 181.9 (s, C-4), 164.4 (s, C-2), 163.3 (s, C-7), 161.5 (s, C-5), 157.4 (s, C-9), 148.6 (s, C-4'), 146.6 (s, C-3'), 124.8 (s, C-1'), 118.6 (d, C-6'), 116.1 (d, C-5'), 110.6 (d, C-2'), 104.1 (s, C-10), 103.9 (d, C-3), 101.2 (d, C-1"), 99.1 (d, C-6), 94.1 (d, C-8), 77.4 (d, C-5"), 75.9 (d, C-3"), 73.3 (d, C-2"), 69.8 (d, C-4"), 60.8 (t, C-6").

All the three compounds were isolated from this plant for the first time. 


\section{Antioxidant activity of target compounds}

Flavonoids are well known to occur in plant extracts and to possess many different biological activities besides antioxidant activity. ${ }^{17-19}$ The off-line DPPH radical scavenging activity of the three target compounds, luteolin-3'- $O$ - $\beta$-D-glucopyranoside (1), luteolin-7$O$ - $\beta$-D-glucopyranoside (2) and luteolin-4'-O- $\beta$-Dglucopyranoside (3), was evaluated. The results showed that compounds 1-3 had potent free radical scavenging capacities with $\mathrm{IC}_{50}$ values of $13.12,9.58$ and $13.65 \mu \mathrm{mol} \mathrm{L}{ }^{-1}$, respectively. Flavonoids with free hydroxyl groups act as free radical-scavengers, and multiple hydroxyl groups, especially on the B-ring, enhance their antioxidant activity, but the glycosylation of 3' or 4'-hydroxyl group tends to reduce the activity. ${ }^{20-22}$ For the three compounds, compound 2 has two hydroxyl groups at the B-ring, while compounds $\mathbf{1}$ and $\mathbf{3}$ have only one hydroxyl group at the B-ring. Therefore, compound $\mathbf{2}$ showed the highest degree of free radical scavenging activity.

\section{Conclusions}

HPLC-RSD-DAD-ESI/MS method followed by HSCCC and NMR experiments was successively developed for the fast screening and purification of isomeric radical scavengers from active fraction of Neo-T. siphonanthun. The best advantage of this method is that the antioxidant compounds can be identified online from a chromatographic separation, and then the target compounds in separation procedures become clear. The results obtained revealed the presence of three radical scavenging components in the active extract of Neo-T. siphonanthun: luteolin-3'-O- $\beta$-D-glucopyranoside, luteolin-7-O- $\beta$-Dglucopyranoside and luteolin-4'-O- $\beta$-D-glucopyranoside. The compounds obtained may be used as reference substances for chromatographic purpose without additional cleanup. The described method has a broad applicability and is rapid, robust and suitable for fast screening and preparing radical scavengers from crude plant extracts.

\section{Acknowledgments}

This work was supported by the National Scientific Foundation of China (No. 20775092) and the China Postdoctoral Science Foundation (No. 2080440991).

\section{References}

1. Sun, X. D.; Bull. Bot. Res. 2000, 20, 9.

2. Ling, Y. R.; Sun, X. D.; Bull. Bot. Res. 2001, 21, 175.

3. Borek, C.; J. Nutr. 2001, 131, 1010S.

4. Hostettmann, K.; Wolfender, J. L.; Terreaux, C.; Pharmaceut. Biol. 2001, 39, 18.

5. Koleva, I. I.; Niederländer, H. A. G.; van Beek, T. A.; Anal. Chem. 2000, 72, 2323.

6. Li, S.Y.; Yu, Y.; Li, S. P.; J. Agric. Food Chem. 2007, 55, 3358.

7. Kosar,M.; Dorman, D.; Baser, K.; Hiltunen, R.; Chromatographia 2004, 60, 635.

8. Pérez-Bonilla, M.; Salido, S.; van Beek, T. A.; LinaresPalomino, P. J.; Altarejos, J.; Nogueras, M.; Sánchez, A.; J. Chromatogr., A 2006, 1112, 311.

9. Wu, J. H.; Huang, C. Y.; Tung, Y. T.; Chang, S. T.; J. Agric. Food Chem. 2008, 56, 328.

10. Shi, S. Y.; Zhao, Y.; Zhou, H. H.; Zhang, Y. P.; Jiang, X. Y.; Huang, K. L.; J. Chromatogr., A 2008, 1209, 145.

11. Nuengchamnong, N.; de Jong, C. F.; Bruyneel, B.; Niessen, W. M. A.; Irth, H.; Ingkaninan, K.; Phytochem. Anal. 2005, 16, 422.

12. Tapia, A.; Rodriguez, J.; Theoduloz, C.; Lopez, S.; Feresin, G. E.; Schmeda-Hirschmann, G.; J. Ethnopharmacol. 2004, 95, 155.

13. Ito, Y.; J. Chromatogr. 1981, 214, 122.

14. Shi, S. Y.; Huang, K. L.; Zhang, Y. P.; Zhao, Y.; Li, H. B.; J. Chromatogr., B 2007, 859, 119.

15. Du, Q. Z.; Xu, Y., Li, L., Zhao, Y., Jerz, G., Winterhalter, P.; J. Agric. Food Chem. 2006, 54, 4186.

16. Wolbis, M; Krolikowska, M.; Acta Pol. Pharm. 1985, 42, 215.

17. Kong, C. S.; Kim, Y. A.; Kim, M. M.; Park, J. S.; Kim, J. A.; Kim, S. K.; Lee, B. J.; Nam, T. J.; Seo, Y.; Toxicol. in Vitro 2008, 22, 1742 .

18. Murakami, A.; Ashida, H.; Terao, J.; Cancer Lett. 2008, 269, 315.

19. Suwalsky, M.; Vargas, P.; Avello, M.; Villena, F.; Sotomayor, C. P.; Int. J. Pharm. 2008, 363, 85.

20. Akdemir, Z. S.; Tatli, I. I.; Bedir, E; Khan, I. A.; FABAD J. Pharm. Sci. 2003, 28, 71.

21. Jovanovic, S. V.; Steenken, S.; Tosic, M.; Marjanovie, B.; Simic, M. G.; J. Am. Chem. Soc. 1994, 116, 4846.

22. Mastuda, H.; Wang, T.; Managi, H.; Yoshikawa, M.; Bioorg. Med. Chem. 2003, 11, 5317.

Received: November 9, 2009 Web Release Date: April 15, 2010 